\title{
Irinotecan Every 14 Days Regimen
}

National Cancer Institute

\section{Source}

National Cancer Institute. Irinotecan Every 14 Days Regimen. NCI Thesaurus. Code

C160068.

A chemotherapy regimen consisting of irinotecan every 14 days that may be used in the treatment of colorectal cancer. 